\title{
UPAYA PENDAMPINGAN MENULIS DAN PUBLIKASI KARYA ILMIAH PENELITIAN TINDAKAN KELAS BAGI GURU SMK DI PENAJAM PASER UTARA
}

\author{
SAIFUL GHOZI ${ }^{1}$, TUATUL MAHFUD ${ }^{2}$, SUBUR MULYANTO ${ }^{3}$, SUPARMANTO ${ }^{4}$ \\ 1,2,3 Politeknik Negeri Balikpapan, Balikpapan, Kaltim \\ ${ }^{4}$ SMKN 2 Penajam Paser Utara, PPU, Kaltim \\ Email: Saiful.ghozi@poltekba.ac.id
}

\begin{abstract}
ABSTRAK
Artikel ini mendeskripsikan upaya peningkatan kemampuan menulis dan teknis publikasi bagi guru SMK di Kabupaten Penajam Paser Utara (PPU) Kalimantan Timur. Upaya ini dilatar belakangi oleh minimnya kemampuan dan waktu guru SMK dalam menghasilkan karya ilmiah. Indikator pentingnya adalah banyak guru- guru yang terhambat naik pangkatnya karena tidak mampu menghasilkan karya ilmiah. Upaya tersebut dilakukan melalui bimbingan dan pendampingan untuk menghasilkan karya ilmiah Penelitian Tindakan Kelals (PTK) dan mempublikasikannya di media publikasi jurnal atau semiar yang relevan. Pendampingan secara teknis juga dilakukan dalam melakukan online submission di sistem jurnal online OJS. Partisipan yang terlibat dalam upaya ini adalah guru SMK 2 di kab PPU. Program ini direncanakan melalui 3 tahapan kegiatan : (i) pelatihan penyusunan karya ilmiah guru, (ii) bimbingan teknis sistem sitasi dan referensi karya ilmiah; (iii) bimbingan teknis sistem submit OJS journal. Tahapan tersebut dilaksanakan dalam kurun waktu 3 bulan. Capaian yang dihasilkan dari kegiatan ini adalah (1) peningkatan motivasi menulis, (2) mitra memiliki kemampuan teknis publikasi di jurnal OJS, (3) dihasilkan draft karya tulis dibidang Penelitian Tindakan Kelals (PTK). Kegiatan pendampingan penulisan dan publikasi artikel PTK secara subjektif-kualitatif dapat meningkatkan motivasi guru dalam melaksanakan PTK. Hal ini dapat dilihat dari draft awal yang dihasilkan sebanyak 12 draft, dan akhirnya tersaring sebanyak 4 draft yang siap terbit di jurnal nasional.
\end{abstract}

Kata kunci : karya ilmiah, PTK, guru SMK.

\section{PEBDAHULUAN}

Menurut Undang-Undang nomor 14 tahun 2005 tentang guru dan dosen, berbeda dengan dosen, guru memang tidak diwajibkan melakukan penelitian atau publikasi ilmiah. Namun, untuk pengembangan karir pada jenjang kepangkatan tertentu, guru wajib memenuhi syarat berupa penulisan karya ilmiah. Hal ini dapat dilihat dalam regulasi Permen PANRB No.16 Tahun 2009 yang mengisyaratkan kenaikan pangkat guru 80\% unsur utama dan 20\% penunjang (Yati \& Sustianingsih, 2021). Dalam regulasi tersebut penulisan karya ilmiah merupakan syarat wajib dari unsur dan sub unsur kegiatan guru. Dapat dikatakan bahwa penulisan karya ilmiah merupakan bagian dari kegiatan pengembangan keprofesian berkelanjutan profesi guru. Namun kinerja penulisan karya ilmiah sering kali menjadi penghambat kenaikan jenjang pangkat bagi guru mengingat rendahnya kemampuan dan minat menulis di kalangan mereka.

Dalam melaksanakan kegiatan keprofesian guru, salah satu cara yang dapat ditempuh untuk menyelesaikan masalah dalam pembelajaran adalah dengan melaksanakan Penelitian Tindakan Kelas (PTK) yang dapat dipublikasikan dalam suatu karya ilmiah (Dwi Susilowati, 2018). Hasil yang diperoleh dalam PTK tersebut dapat didokumentasikan dalam publikasi karya ilmiah yang pada akhirnya menjadi poin penting dalam penilaian kinerja guru. Dibutuhkan kemauan yang tinggi bagi guru untuk bisa menghasilkan kinerja tersebut. Sayangnya, pada poin tersebut banyak guru mengalami hambatan. Disisi lain pembinaan dan intervensi program- program dinas pendidikan masih minim untuk meningkatkan kemampuan guru menulis. 
Diluar jangkauan pembinaan dinas pendidikan terkait, terdapat potensi pendampingan dan resource sharing dari unsur perguruan tinggi melalui skema tridharma perguruan tinggi. Sehingga beberapa dosen di perguruan tinggi telah melakukan sharing ide, gagasan dan kemampuan dalam meningkatkan kemampuan menulis karya ilmiah khususnya pada guru SMK melalui skema pengabdian kepada msyarakat. Salahsatu kegiatan pendampingan penulisan artikel ilmiah guru SMK dilakukan oleh Oktoviana et al., (2020) melalui kegiatan pendampingan yang dilakukan pada guru SMK di kota Kediri, Jawa Timur. Kegiatan tersebut diikuti sebanyak 61 guru SMK dan dilaksanakan melalui tahapan (1) Pemberian materi tentang karya ilmiah dan anatomi dari artikel ilmiah, (2) presentasi contoh artikel yang ditulis berdasarkan hasil PTK oleh alumni Jurusan Matematika UM, dan (3) pendampingan guru-guru peserta dalam praktek penulisan artikel ilmiah dari hasil PTK yang sudah disiapkan masingmasing guru. Setelah mengikuti pelatihan dan pendampingan penulisan artikel ilmiah oleh tim pengabdian Jurusan Matematika Universitas Negeri Malang tersebut, guru-guru matematika SMK Kota Kediri merasa lebih percaya diri dalam menuliskan artikel ilmiah. Keberanian dalam menuliskan artikel ilmiah ini dimulai dari menuliskan judul yang tepat dan efektif kemudian dilanjutkan dengan menuliskan latar belakang yang sesuai dengan kondisi dan tujuan yang ingin dicapai.

Kegiatan serupa juga dilakukan oleh Irwansyah, dkk (2020). Kegiatan pelatihan penulisan artikel ilmiah diberikan kepada 30 SMK Negeri 1 Denpasar. Kegiatan tersebut melalui tahapan: (1) sosialisasi dan bimbingan teknis penulisan artikel ilmiah, (2) pelatihan dan pendampingan penulisan artikel ilmiah sebanyak tiga kali kegiatan, (3) Focus Group Discussion ( $F G D$ ) dalam rangka evaluasi pelaksanaan kegiatan (satu kali pertemuan). Kegiatan tersebut dinilai mampu meningkatkan pengetahuan dan kemampuan peserta dalam menulis artikel ilmiah. Selain itu, pelaksanaan pengabdian kepada masyarakat dengan menyasar guru sebagai peserta dinilai sangat tepat dilakukan untuk meningkatkan kompetensi guru.

Selain itu, kegiatan pendampingan penulisan karya ilmiah juga dilakukan oleh Hasanah, dkk (2020) secara online (daring) sesuai kondisi pandemi. Kegiatan pelatihan ini dilaksanakan dengan 3 tahap, tahap yang pertama yaitu persiapan, kedua pelaksanaan secara daring, dan ketiga evaluasi. Kegiatan yang dilaksanakan secara daring tersebut tentu memunculkan pertanyaan sejauh mana efektifitasnya meskipun ada instrument evaluasi pengukuran efeknya. Berangkat dari kondisi mitra dan referensi tahapan kegiatan- kegiatan serupa, maka penulis merasa perlu menyelenggarakan pelatihan menulis artikel dengan sasaran guru-guru SMK di kabupaten Penajam Paser Utara, Kalimantan Timur. Fokus penulisan diarahkan khusus pada penulisan artikel ilmiah yang berkaitan dengan penelitian Pendidikan khususnya Penelitian Tindakan Kelas (PTK). Hal ini mengingat karya tulis yang diakui angka kredit bagi guru PNS adalah artikel tentang PTK. 


\section{METODE PELAKSANAAN}

Tahapan upaya peningkatan kemampuan menulis dan teknis publikasi bagi guru SMK ini disajikan dalam gambar 3 berikut.

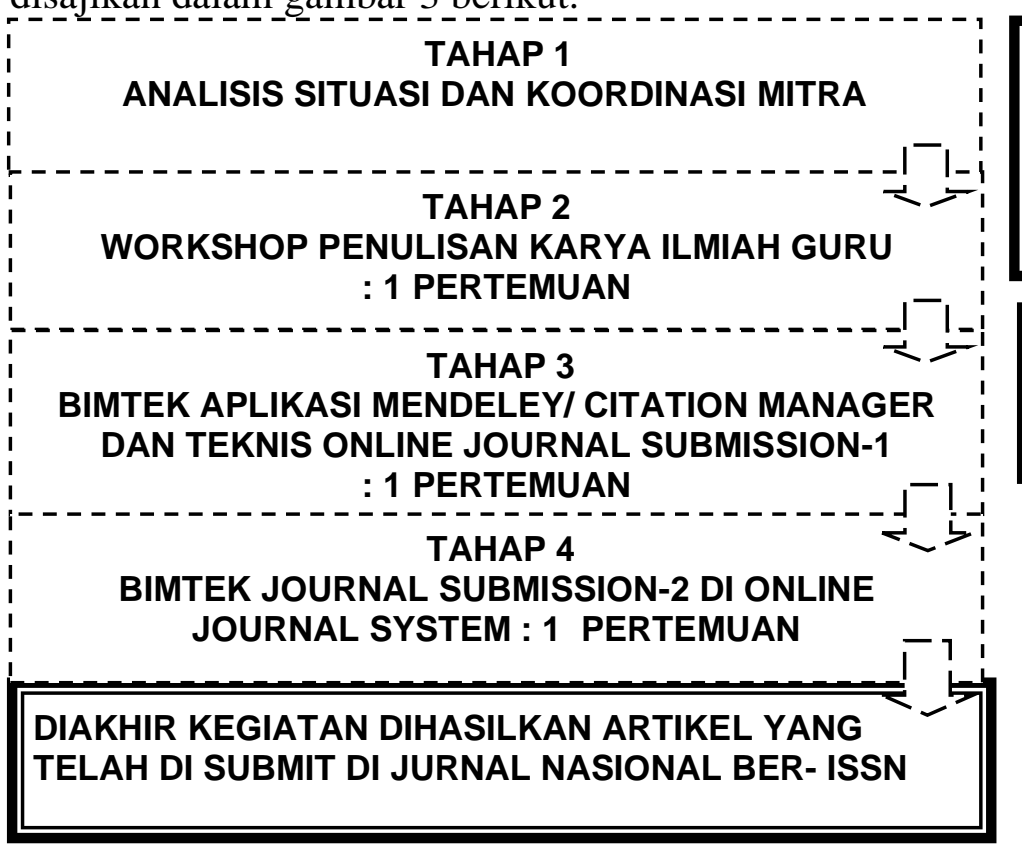

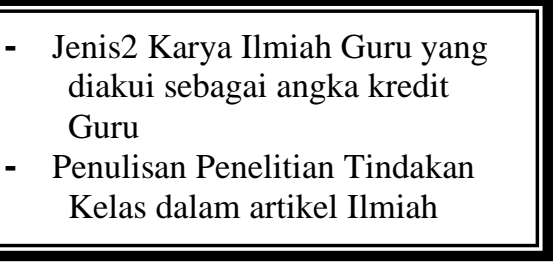

Kemampuan teknis

\section{Gambar 3. Tahapan Kegiatan Pengabdian kepada Masyarakat}

Semua tahapan diatas dideskripsikan dalam sebuah paparan yang membentuk penelitian deskriptif yang menyajikan fakta dan data yang bernilai saintifik-kualitatif (Creswell, 2009).

\section{HASIL DAN PEMBAHASAN}

\section{Tahap 1 Analisis Situasi Dan Koordinasi Mitra}

Dalam rangka memberikan gambaran kondisi mitra, maka dilakukan analisis situasi terhadap mitra melalui instrument kuisioner melalui google form (dapat diakses di https://bit.ly/2XiefaW). Survey disebarkan ke 50 responden, namun hanya 16 responden yang mengisi kuisioner sampai batas waktu yang ditetapkan. Hasil kuisioner tersebut adalah sebagai berikut.

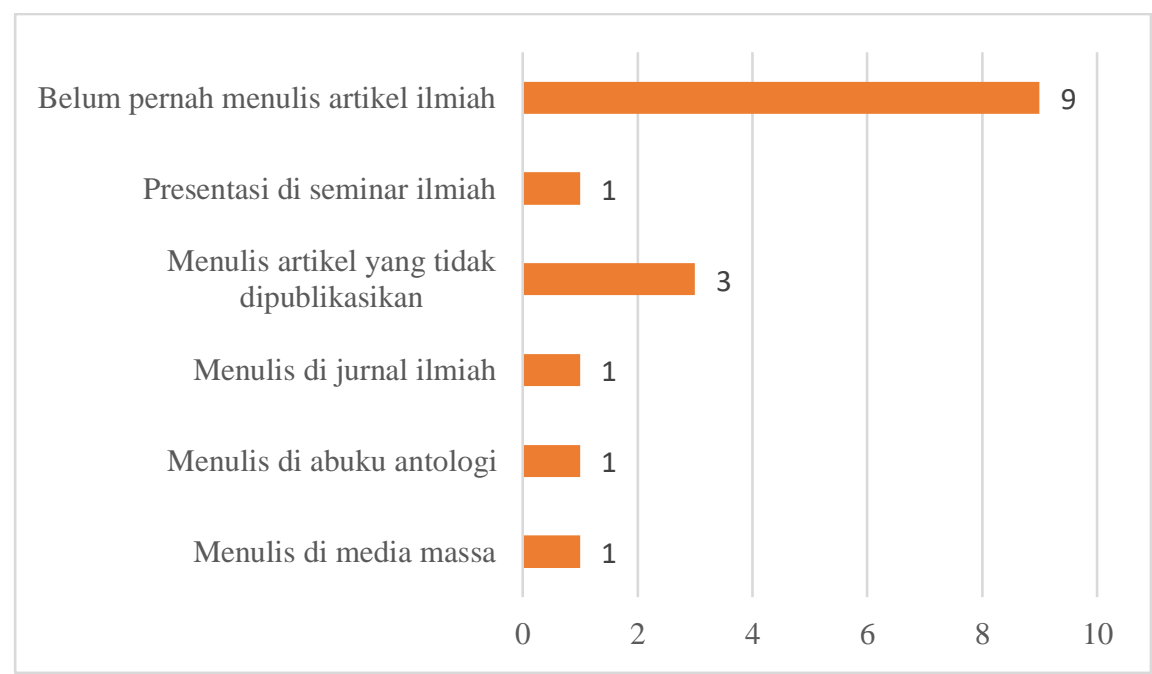

Gambar 1. Hasil Survey Pengalaman Menulis Guru SMK di PPU

Dari gambar 1 diatas terlihat bahwa beberapa guru sudah memiliki pengalaman menulis di beberapa media publikasi. Ini menggambarkan bahwa kegiatan menulis bukan suatu hal yang sama sekali asing bagi guru. Namun, guru yang memiliki pengalaman tersebut baru segelintir 
orang. Diharapkan beberapa guru yang sudah berpengalaman mampu memberikan dampak yang lebih luas terhadap guru lainnya yang mayoritas masih belum memiliki pengalaman. Motivasi dan sharing yang dibagikan secara formal yang melibatkan guru tersebut diharapkan mampu menambah semangat guru yang lain.

Motivasi utama saya menulis adalah
13 responses

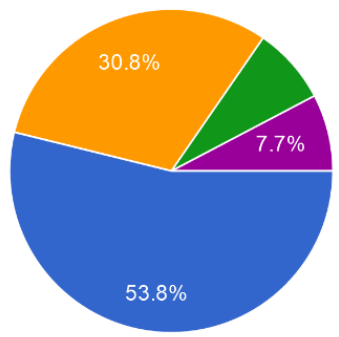

Membangun eks/stensi ide/gagasan. Hobi

Meraih angka kredit untuk naik pangkat

Pelengkap bahan ajar

Belajar buat artikel

\section{Gambar 2. Hasil Survey Motivasi Menulis Guru SMK di PPU}

Membangun eksistensi diri dan dalam upaya mempeoleh angka kredit adalah dua motivasi penting bagu mitra guru dalam menulis karya ilmiah. Hal ini menjadi catatan penting bagi kebutuhan para guru. Sentuhan pelatihan yang terbatas dari dinas Pendidikan terkait dapat dikolaborasikan dengan potensi perguruan tinggi seperti Politeknbik Negeri Balikpapan melalui sumberdaya dana pengabdian kepada masyarakat.

Berikut disajikan kata kunci yang diperoleh dari jawaban responden atas pertenyaan apa kendala dan hambatan dalam menulis karya ilmiah.

Tabel 1 Kata kunci pertanyaan terbuka kuisioner

\begin{tabular}{lll}
\hline No & Kata kunci & Jumlah \\
\hline 1 & Bagaimana memulai tulisan artikel & 3 \\
\hline 2 & Menyempurnakan ide & 1 \\
\hline 3 & Cara menulis artikel & 1 \\
\hline 4 & Menuangkan gagasan & 1 \\
\hline 5 & Menentukan siklus PTK & 1 \\
\hline 6 & Pengolahan data & 1 \\
\hline 7 & Perlu pembimning & 1 \\
\hline 8 & Menemukan ide & 1 \\
\hline
\end{tabular}

Dari tabel 1 diatas dapat dijelaskan beberapa kendala dan hambatan guru dalam menghasilkan karya ilmiah. Pertama, rendahnya minat membaca dan minat menulis. Aktivitas menulis tidak bisa dilepaskan dari aktivitas membaca. Selama ini guru lebih banyak disibukkan dengan aktivitas mengajar di kelas sehingga kewajiban membaca untuk pengembangan dirinya menjadi tidak terpenuhi. Kedua, keterbatasan ketersediaan bahan bacaan yang bisa menjadi bahan tulisan. Ketiga, tidak adanya rasa percaya diri dan kurangnya pengalaman untuk menulis. Keempat, ketidakpahaman guru atas bekal-bekal keilmuan untuk bisa terampil menulis. Kelima, rendahnya motivasi untuk menulis.

Selain itu, melalui wawancara dengan beberapa guru SMKN 2 Penajam Paser Utara, didapatkan beberapa poin penting dari transkrip wawancara yaitu (1) Sudah ada beberapa guru yang menulis artikel di jurnal ilmiah; (2) Kegiatan menulis artikel ilmiah belum mampu menjangkau atau menembus jurnal-jurnal ilmiah di perguruan tinggi atau jurnal berskala nasional; (3) Perlu adanya pendampingan yang berkelanjutan dari berbagai pihak agar aktivitas menulis artikel ilmiah para guru bisa berkembang. 


\section{Tahap 2 Bimtek Aplikasi Mendeley/ Citation Manager dan Teknis Online Journal Submission (OJS)}

Kegiata tatap muka pertama dilaksanakan tanggal 9 September 2021. Pada sesi pertama disajikan materi tentang pengenalan jenis- Janis karyai ilmia. Mengenal istilah draft, manuskrip, artikel jurnal, artikel prosiding. Mitra juga diberi sosialisasi tentang tingkatan jrunal dari mulai jurnal nasional tak terakreditas, terskreditasi hingga jurnal internasional. Selain itu dilakukan simulasi register akun di OJS jurnal di system OJS jurnal Poltekba di laman http://jurnal.poltekba.ac.id. Tahapan tersebut terdokumentasi dalam gambar 3.

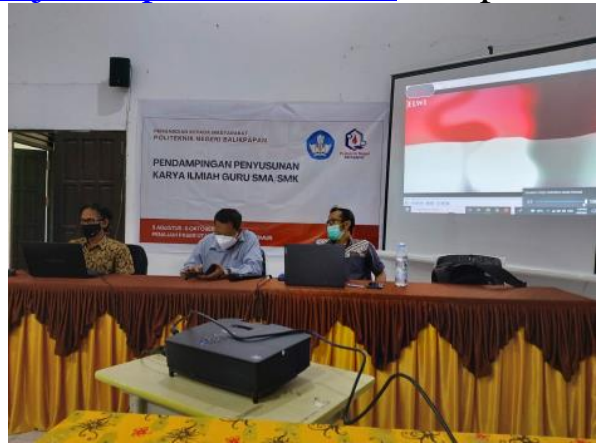

A

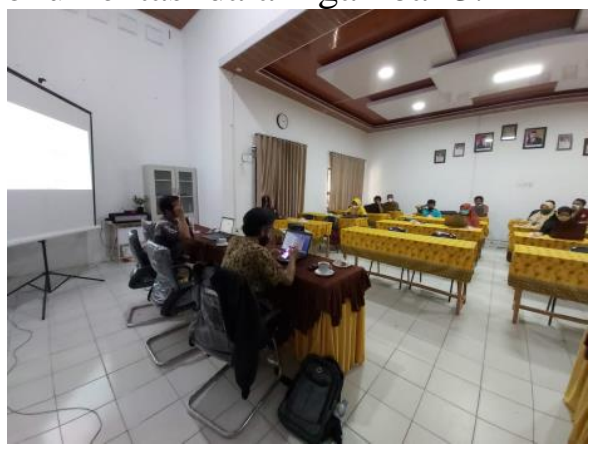

$\mathrm{b}$

Gambar 3 (a) Acara pembukaan oleh kepala sekolah SMKN 2 PPU, (b) Pemberian materi tentang jenis- jenis karya ilmiah

Dalam kesempatan tersebut juga dijaring beberapa draft artikel dari peserta untuk di submit secara online di system OJS jurnal Poltekba untuk selanjutnuya dilakukan supervise dari mulai template hingga subtansi artikel. Dari 13 peserta, 8 guru berhasil melakukan submit artikel di OJS jurnal. Tahapan tersebut terdokumentasi dalam gambar 4.

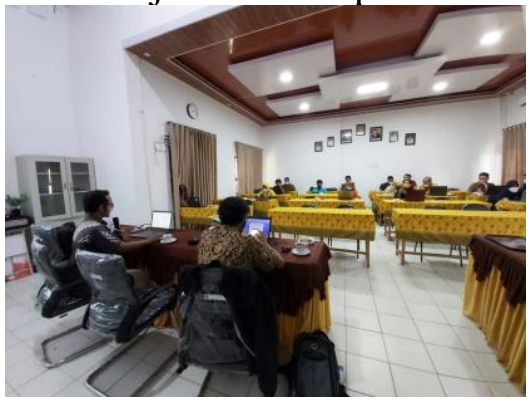

a

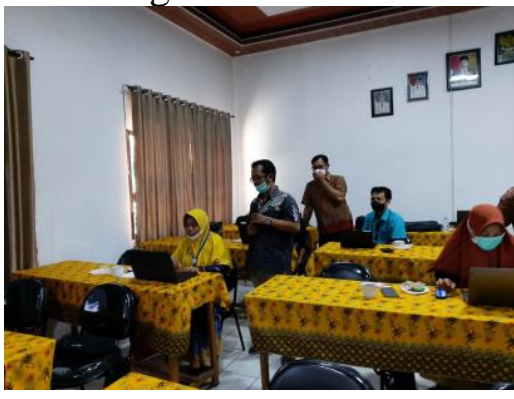

b

Gambar 4 (a) Sajian materi pengenalan jurnal, (b) Simulasi submit artikel melalui OJS jurnal Poltekba.

\section{Tahap 3 Workshop Penulisan Karya Ilmiah PTK Guru SMK}

Pada sesi kedua yang dilaksanakan tanggal 16 September 2021, disajikan materi tentan Penelitian Tindakan Kelas (PTK) yang disampaikan oleh Dr Tuatul Mahfud, M.Pd. Dalam penyajian materi tersebut mitra mendapat wawasan/ penyegaran materi tetaang PTK dan tips menulis karya ilmiah dari kegiatan keseharian mengajar guru.

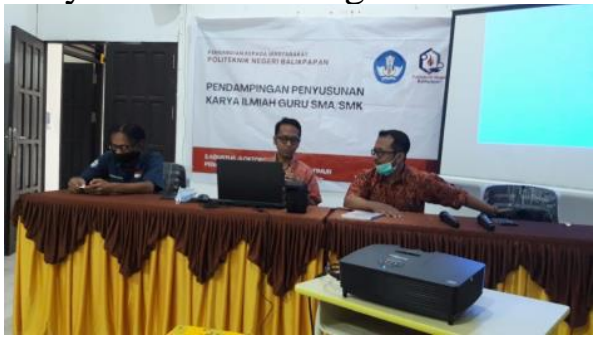

a

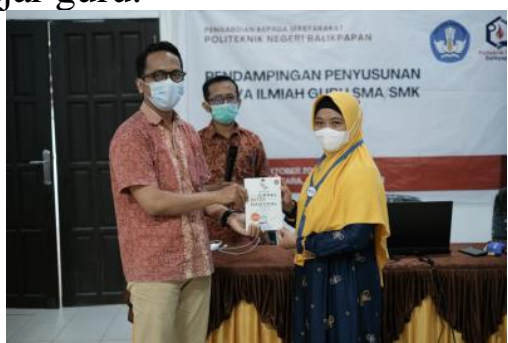

b

Gambar 5 (a) Sajian materi tentang PTK oleh Pak Dr. Tuatl Mahfud, (b) Pemberian buku bagi peserta yang menghasilkan draft yang siap publis 
Beberapa draft yang dihasilkan dilakukan supervise layout dari Bp Saiful Ghozi dalam perspektif editor. Selanjtnya mendapat masukan subtansi dari Bp Tuatul Mahfud. Dalam kesempatan tersebut peserta yang paling aktif mendapat hadiah satu buku karya Dr Tuatul Mahfud, MpD, yang berjudul “ Tips Menulis Artikel Jurnal Internasional”. Hadiah tersebut diberikan kepada salahsatu guru Bahasa inggris yang berhasil menghasilkan draft artiel ilmiah PTK, yakni Ibu Zainatul Fitriyah, M.Pd. Tahapan tersebut terdokumentasi dalam gambar 5.

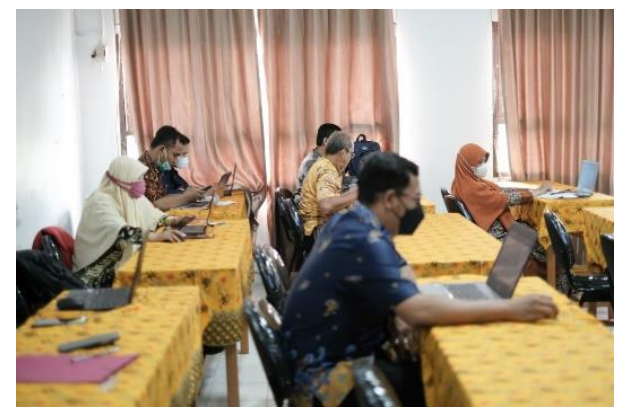

a

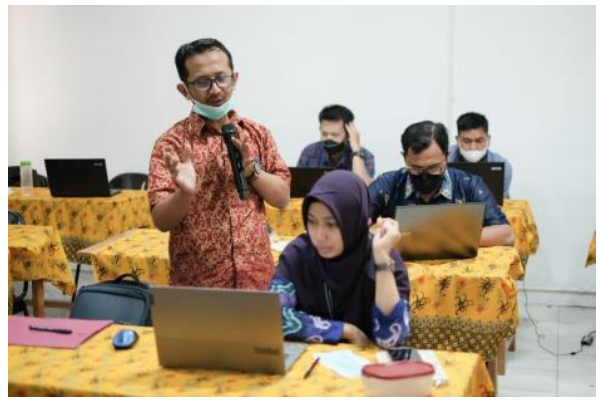

b

Gambar 6 (a) Pembuatan draft artikel (b) Review draft artikel

Dari hasil survey awal dihasilkan kesimpulan bahwa mayoritas guru masih memiliki motivasi dan wawasan yang rendah dalam menulis karya ilmiah. Motivasi menulis karya ilmiah masih tergolong prakmatis, yakni untuk memenuhi kebutuihan angka kredit kenaikan pangkat terutama menuju pangkat golongan 4A keatas. Kebutuha jenis karya tulis untuk guru sejauh ini masih terbatas karya tulis tentang Peneltian Tindakan Kelas untuk bisa diakui sebagai angka kredit dalam kenaikan pangkat. Untuk itu wawasan teknis terkait bagimana penulisan artikel karya ilmiah PTK perlu mendapat refres materi. Tahapan tersebut terdokumentasi dalam gambar 6.

Mitra peserta pendampingan juga berhasil melakukan simulasi onlie submission di jurnal OJS Poltekba, serta pembuatan akun Google scholar. Dalam kesempatan tersebut mitra guru juga dikenalkan bebrapa fitur penting dalam menulis karya ilmiah seperti Mendeley, Plagiarism Checker, dan fitur pencairan artikel di portal Garuda dan Sinta.

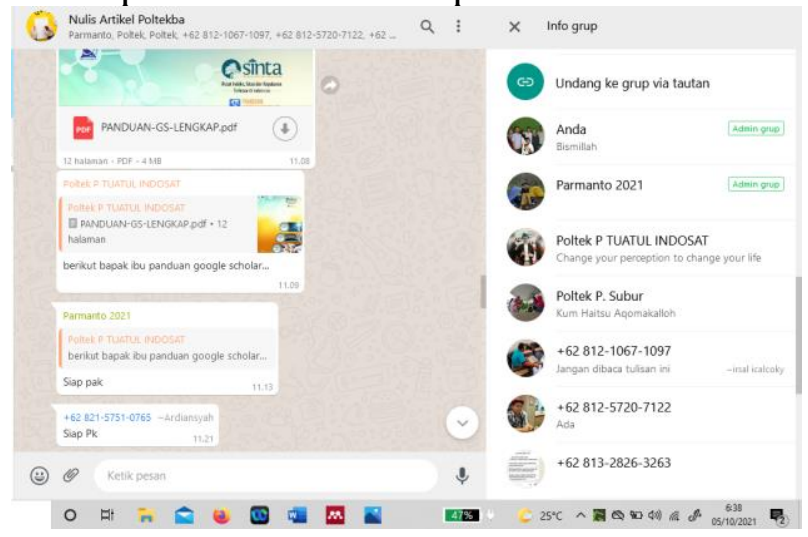

\section{Gambar 7. Whatsapp Group dalam rangka komunikasi pendampingan review draft yang dihasilkan mitra guru SMK.}

Dalam membangun keberlanjutan pendampingan maka dibuat juga media komunikasi bersama dalam rangka review draft artikel hingga maksimal 3 bulan pasca kegiata sebagaimana terlihat di gambar 7. Diharapkan dari rangkaian kegiatan pendampingan ini selain ada peningkatan wawasan dan motivasi juga dihasilkan draft yang siap terbit. Total draft yang dihasilkan dari kegiatan pendampingan ini sebanyak 5 draft yang memenuhi kriteria untuk bisa diberi pendampingan review subtansi lebih lanjut. 
Pemaparan urgensi dan intervensi pembinaan guru SMK dalam peningkatan kompetensi PTK juga dipaparkan oleh Prasetiani, (2014). Dimana manfaat karya tulis ilmiah tidak hanya dapat dirasakan oleh peserta didik, tetapi juga oleh kolega guru lainnya dan masyarakat luas. Karya ilmiah juga merupakan nilai profesionalisme dari seorang guru, karena kegiatan menulis karya ilmiah mendukung profesi guru, baik dalam proses belajar dan mengajar ataupun dalam berdiskusi untuk memecahkan masalah tertentu yang diajukan.

Minimnya wawasan, kemampuan teknis submit, dan motivasi guru dalam menghasilkan publikasi karya ilmiah menjadi kendala bagi para guru khususnya guru SMK. Hal ini sejalan dengan latar belakang kegiatan yang dilakukan oleh Oktoviana et al., (2020). Kolaborasi yang sinergis antara insan perguruan tinggi dan mitra guru SMK merupakan potensi sumberdaya yang mampu meningkatkan kualitas menulis guru. Tingkat keberhasilan upaya ini sejalan dengan paparan yang sampaikan oleh Giyarsih, (2021) bahwa intervensi pembinaan dan sharing informasi mampu membuka wawasan dan motivasi guru dalam menghasilkan draft artikel PTK. Namun demikian, kegiatan lain kedepan diharapkan adanya peningkatan intensitas, serta strategi pendampingan yang lebih efektif dengan mengutamakan luaran yang konkrit yakni berupa realisasi PTK dan draft publikasi yang siap dipublikasikan.

\section{KESIMPULAN}

Secara umum ada beberapa kendala yang bisa ditemukan sehingga membuat tingkat partisipasi menulis di kalangan guru ini rendah. Pertama, rendahnya minat membaca dan minat menulis. Aktivitas menulis tidak bisa dilepaskan dari aktivitas membaca. Selama ini guru lebih banyak disibukkan dengan aktivitas mengajar di kelas sehingga kewajiban membaca untuk pengembangan dirinya menjadi tidak terpenuhi. Kedua, keterbatasan ketersediaan bahan bacaan yang bisa menjadi bahan tulisan. Ketiga, tidak adanya rasa percaya diri dan kurangnya pengalaman untuk menulis. Keempat, ketidakpahaman guru atas bekal-bekal keilmuan untuk bisa terampil menulis. Kelima, rendahnya motivasi untuk menulis. Mengingat pentingnya ketrampilan menulis karya ilmiah bagi guru, diharapkan ada pembinaan dan penghargaan dari pihak sekolah maupun dinas terkait. Kegiatan pendampingan penulisan dan publikasi artikel PTK secara subjektif-kualitatif dapat meningkatkan motivasi guru dalam melaksanakan PTK sehingga diharapkan profesi guru meningkat. Hal ini dapat dilihat dari draft awal yang dihasilkan sebanyak 12 draft, dan akhirnya tersaring sebanyak 4 draft yang siap terbit di jurnal nasional.

\section{DAFTAR PUSTAKA}

Creswell, J. W. (2009). Research Design: Qualitative, Quantitative, and Mixed Methods Approaches, $3 r d$ ed (3rd ed.). California: SAGE Publications Inc.

Dwi Susilowati. (2018). Pembelajaran, penelitian tindakan kelas (PTK) solusi alternatif problematika. Jurnal ilmiah edunomika, 2(1), 36-46. https://doi.org/http://dx.doi.org/10.29040/jie.v2i01.175

Giyarsih, G. (2021). Peningkatan Kompetensi Guru Untuk Mengembangkan Profesi Melalui Pembimbingan Penulisan PTK Bagi Guru SMK GURU SMK. VOCATIONAL: Jurnal Inovasi Pendidikan Kejuruan, 1(3), 93-100. https://doi.org/https://doi.org/10.51878/vocational.v1i3.351

Hasanah, F. N., Megawati, F., Shofiyah, N., Jannah, M., \& Rindiani, R. (2020). Pelatihan Daring Penulisan Artikel Ilmiah Bagi Guru Sekolah Menengah Kejuruan Negeri 1 Sidoarjo. JPM (Jurnal Pemberdayaan Masyarakat), 5(2), 515-521. https://doi.org/https://doi.org/10.21067/jpm.v5i2.4414

Irwansyah, M. R., Maysanjaya, I. M. D., \& Tripalupi, L. E. (2020). Pelatihan Penulisan Artikel Ilmiah Hasil Penelitian Tindakan Kelas bagi Guru Smk Negeri 1 Denpasar. Proceeding Senadimas Undiksha 2020, 1050-1055. Retrieved from https://lppm.undiksha.ac.id/senadimas2020/assets/ProsidingSenadimas2020/file/138. pdf 
Oktoviana, L. T., Hasanah, D., Sulandra, I. M., Susiswo, S., Lestari, rianingsih E., \& Nurhakiki, R. (2020). Pendampingan Penulisan Artikel Ilmiah dari Hasil Penelitian bagi Guru Matematika SMK Kota Kediri. ABDIMAS: Jurnal Pengabdian Masyarakat Universitas Merdeka Malang, 5(2), 115-122. Retrieved from https://jurnal.unmer.ac.id/index.php/jpkm/article/view/3820

Prasetiani, D. (2014). Peningkatan Kompetensi Penelitian Tindakan Kelas bagi Guru Bahasa Jepang SMA/SMK Se-Kota SemaranG. Jurnal Abdimas, (Vol 18, No 1 (2014)). Retrieved from http://journal.unnes.ac.id/nju/index.php/abdimas/article/view/5720

Yati, R. M., \& Sustianingsih, I. M. (2021). Workshop dan Pendampingan Penulisan Artikel Ilmiah Bagi Guru-guru Sejarah Kabupaten Musi Rawas Utara. Journal of Abdimas Siliwangi, $\quad 4(2), \quad 371-384 . \quad$ https://doi.org/DOI: http://dx.doi.org/10.22460/as.v4i2p\%25p.4013 